\title{
The design of action research experimental campaigns
}

\author{
A. J. DALZELL WARD \\ Health Education Council, London
}

There is little evidence that mass indiscriminate health education campaigns have any direct effect upon behaviour. However, they are undoubtedly valuable in cultivating public opinion and, in the case of venereal diseases, they have been responsible for raising the level of acceptability of this topic in general discussion. This paper outlines a new type of experimental campaign which aims at a specific target group in the population, is confined to a limited geographical area, and attempts to achieve an integration of research methods with the necessary action in order to influence behaviour. This type of campaign has evolved largely as a result of the contribution of the behavioural and social sciences to health education during recent years.

The research required for such a campaign is of two kinds.

(1) Before the campaign is mounted it is necessary to study the target group in the population, to ascertain the incidence of disease in that group, in other words to assess their vulnerability, and to be fully informed with regard to the demographic characters of the area in which the operation will be carried out. It is preferable to choose an area where such statistical investigations can be facilitated by the co-operation of health departments and hospital clinics. This preliminary research is then a guide to the communications approach to the target group and also provides a base-line of data from which to measure progress at the end of the campaign.

(2) There is, however, a second type of research required in which measurements are made of the impact of a communications method on the target group. In selecting an objective for the campaign, epidemiological information is essential, and a choice can be made of a contemporary problem capable of solution or improvement which can be measured over a relatively short space of time.

\section{The area chosen}

The Health Education Council decided to organize an action research campaign in an area comprising two inner London boroughs with a combined population of about 700,000 . There are a number of special clinics serving the area but it is known that 50 per cent. of patients who are domiciled in the study area attend the special clinic at St. Thomas's Hospital, either because of symptoms or because they are aware they have run the risk of sexually transmitted infection. The remainder of the patients attend a number of clinics in or adjacent to the study area and it is also known that a number are treated by their general practitioners. This area, therefore, possesses all the criteria as a suitable area for this type of campaign, as it is possible to secure the cooperation of venereologists, medical officers of health and the staffs of the two large health departments involved, general practitioners, and social workers.

\section{The objective}

It was decided that an improvement in the rate of contact tracing in cases of gonorrhoea would be the primary objective of the campaign. In addition, an attempt would be made to interest the public in the problem of the spread of gonorrhoea and its control, and throughout the campaign interest was to be limited to the problem of gonorrhoea. It was also decided to limit the message aimed at the target group in the population to the question of the prevention of spread of infection, by urging all those who had run the risk of infection to report for diagnosis and treatment before there was an opportunity of infecting another person.

\section{The target group}

All the data available point to the age group 18 to 24 years of both sexes as being the most sexually active in the population as well as most at risk of contracting sexually transmitted diseases. The main message of the campaign, therefore, was designed to be attractive to this age group. Sexual promiscuity 
is now recognized as the factor underlying vulnerability to sexually transmitted infections, and this was implicit in the messages contained in the various displays and literature which formed the communications part of the exercise. The problem was approached realistically, as is necessary in a permissive age, and as the campaign avoided any moralizing it offered a rational basis for monogamous unions whether marital or extra-marital.

\section{Organization}

The first step was to set up a Steering Committee comprising representatives of The Health Education Council, St. Thomas' Hospital, and the Public Health Departments of the two boroughs concerned. In the case of The Health Education Council, the Communications Division and the Medical Research Division were both represented and the Steering Committee was under the Chairmanship of the Chief Medical Officer of the Health Education Council. This Steering Committee was responsible mainly for the co-ordination of the parallel efforts which have been made to undertake the original base-line researches to prepare and develop communications methods and to organize health education activities in the area. The effect was the formation of a Joint Task Force which will pursue this campaign for a period of at least 12 months.

\section{The communications exercise}

The general message of the campaign which has been indicated above was translated into visual and verbal terms by the design and construction of two types of animated illuminated display. The campaign itself is denoted by a specially designed symbol intended to indicate the fact that carriers of gonorrhoea are circulating in the population. In deciding on the message and the terms to be used, advice was taken from the venereologists on the Steering Committee. When the campaign message had been clarified its translation into popular terms was handed over to a commercial advertising agency in the case of the leaflet and to an exhibitions contractor in the case of the displays. It was found desirable to have two approaches in the clinics, one for men and one for women, in view of the fact that many of the contacts attending for treatment in the women's clinics have been infected by their husbands. It was felt in the case of women that the so-called 'soft sell' would be preferable.

In addition to the displays and leaflet an $8 \mathrm{~mm}$. film has been commissioned for showing in clinics by back projection. The campaign message has been translated into an animated cartoon and this will be shown continuously in the clinics, thus reinforcing the message of the display.

A preliminary press announcement was issued before the commencement of the campaign and it is hoped also to have the co-operation of local radio.

Of the two types of display, that intended to approach the target group in the general public will be sited in six colleges of education or advanced technology and in six selected public sites in the area concerned. The other type of display is intended for use in clinics and the impact of this display will be studied in the main clinic before it is offered to other clinics serving the area.

\section{Communications research}

A commercial research agency has been commissioned to undertake the monitoring of the public response to the display material and films. The research method will take the form of interviews with a sample of the population concerned. The interviews will be structured using questionnaires and will be undertaken before the campaign begins, to establish a base-line, and then at least once during the campaign, and finally at the conclusion of the campaign. The sites for the displays already mentioned are the initial sites and this does not prejudice displays being moved either to other colleges or to other public sites during the course of the campaign. However, the communications research will concentrate on the samples drawn from the population at the beginning of the campaign.

\section{Statistical research}

This is being carried out by the Medical Research Division of the Health Education Council and will concentrate on the clinic population. A team of research workers has been mobilized to undertake data collection and analysis. This team includes a Systems Analyst who has also undertaken an analytical plan of the whole campaign from the initial preparatory stages until its conclusion. In order to cope with additional contact tracing and also with data collection and other tasks connected with research, three Research Officers have been appointed. These will be allocated to different points in the area under study and they will be directly responsible to the Steering Committee. An initial training period of 6 weeks has been organized for these Research Officers so that they can become familiar with the techniques and methods of contact tracing. They will, however, work with the research in mind as well as the practical task of following up possible contacts. 


\section{Summary}

This is a very brief outline of the scheme which began on June 1,1972 . It must, therefore, be regarded as an interim report serving merely to illustrate the basic principles of action research campaigns. This campaign is characterized by the limitation of objective and target group, by the insistence on thorough evaluation at all stages of planning and operation and by the deployment of a very large task force which is truly multidisciplinary. It is only possible to mount such campaigns with substantial resources both of finance and personnel, but as such campaigns contain a large element of research and development, for example the costs of the displays is substantially higher than if they were mass produced, it is hoped that the results will eventually be available at a national level when the cost would be considerably lower.

Although the objective might appear to be very limited, we expect that much will be learned in a wider area which can then be employed in further campaigns in which new objectives are defined. Certainly, if one can make progress in the problem of contact tracing, this is a further step forwards in the control of the spread of gonorrhoea and there is also the possibility that those in the target age group who have, so far, not run the risk of infection may be helped to recognize their personal responsibility in this respect.
Les caractéristiques de la mise en oeuvre des campagnes de recherche expérimentale

SOMMAIRE

Ceci est un très bref canevas du plan qui a commencé le ler Juin, 1972. Il doit donc être considéré comme un rapport intérimaire servant seulement à faire valoir les principes fondamentaux de la mise en oeuvre des campagnes de recherche. Une telle campagne est caractérisée par la limitation des sujets fixés comme objectifs, par la nécessité d'insister sur l'évaluation minutieuse à toutes les étapes de l'organisation et de l'opération et par la constitution d'un très large groupe de travail réellement multidisciplinaire. Il est possible d'organiser de telles campagnes seulement si l'on dispose de ressources importantes, tant du point de vue du budget que du personnel, mais, comme de telles campagnes comportent un large élément de recherche et de développement-par exemple, le coût des diverses réalisations est subtantiellement plus élevé que si celles-ci étaient menées sur une grande échelle- on espère que les résultats seront éventuellement utilisables au niveau national là où le coût diminuerait considérablement. Quoique l'objectif puisse paraitre très limité, nous espérons que l'on pourra apprendre beaucoup, dans un domaine plus étendu, qui pourra alors être employé dans des campagnes ultérieures pour lesquelles de nouveaux objectifs seront définis. Il est certain que si l'on peut faire des progrès dans la recherche des contacts, ce sera une nouvelle étape vers la maîtrise de l'extension de la gonococcie et, en outre, il y a là une possibilité que la population du groupe d'âge concerné, qui n' a, jusqu' ici, pas couru le risque d'infection, puisse être aidée à prendre conscience de sa responsabilité personnelle à ce sujet. 